\title{
Dry matter yield, chemical composition and estimated extractable protein of legume and grass species during the spring growth $\dagger$
}

\author{
Zeinab Solati, ${ }^{*}$ Uffe Jørgensen, Jørgen Eriksen and Karen Søegaard
}

\begin{abstract}
BACKGROUND: Knowledge of the variation of extractable protein amount in legumes and grasses as affected by harvest time is important for identifying optimal combinations to enable a high protein production in a biorefinery. The extractability of protein was estimated using the Cornell Net Carbohydrate and Protein System across six harvests during the spring growth.

RESULTS: The estimated extractable protein $\left[\mathrm{g} \mathrm{kg}^{-1}\right.$ dry matter (DM)] defined as the easily available fractions $B_{1}+B_{2}$ was significantly higher in white clover and lucerne at all harvests while, if the more cell wall attached fraction $B_{3}$ can be extracted, white clover had the highest extractable protein amongst all species. Total yield of $B_{1}+B_{2}$ per ha was higher in white clover and red clover at the early growth while $B_{1}+B_{2}+B_{3}$ was by far the highest for red clover through all harvests.

CONCLUSION: White clover could be a good candidate for protein production purpose in a biorefinery due to its high extractable protein content per kg DM. In order to maximise the protein production capacity, harvest should take place during early growth due to a decline in protein extractability with maturity. The final economy of the concept will depend on the value of the fibre after extraction of the protein.

(c) 2017 Society of Chemical Industry
\end{abstract}

Keywords: Cornell Net Carbohydrate and Protein System (CNCPS); protein fractions; grassland species; biorefinery; feed

\section{INTRODUCTION}

Europe imports large amounts of protein for animal production in the form of soybean meal mainly from South America, which has resulted in concerns among consumers, governments and non-governmental organisations, that, for example, the increasing dependency on imported soybean meal makes the livestock sector vulnerable to price volatility. ${ }^{1}$

Accordingly, there is an increasing demand for new sources of protein in the European Union (EU) as alternatives to imported soybean meal for livestock production. Legumes and grasses have high protein content with good composition of amino acids (high in lysine and methionine). ${ }^{2}$ The production systems for forage legumes such as clover and lucerne differ from those of grain legumes such as soybean in the way they provide additional and enhanced environmental benefits such as a higher soil carbon storage and biodiversity effects, ${ }^{3,4}$ and perennial crops are able to utilise nutrients more efficiently with lower losses of, for example, nitrate. $^{5}$

Many studies have investigated the quality of protein with regard to its availability to animals using the Cornell Net Carbohydrate and Protein System (CNCPS).$^{6-9}$ CNCPS fractionates the crude protein $(\mathrm{CP})$ based on solubility in the protein precipitant agents, buffer and detergent solutions. ${ }^{10}$ According to this system, protein is fractionated into the fractions $A, B$ and $C$, where fraction $A$ is non-protein nitrogen, fraction $B$ is true protein, and fraction $C$ is bound or unavailable protein. Fraction $B$ is further sub-divided into $B_{1}, B_{2}$ and $B_{3}$ based on decreasing solubility. In our study, CNCPS was utilised in order to estimate the extractability of the protein in the biorefining process. Our assumption was that the CNCPS protein fractions correlate with protein extractability.

A green biorefinery utilises green whole crops such as grasses and legumes for manufacture of chemicals, materials and fuels and for a sustainable production of value added products such as protein. ${ }^{11}$ Lucerne is a valuable forage crop that is used for production of protein in the biorefinery, with the added advantages of reducing crop nitrogen fertiliser requirements due to its nitrogen-fixing ability. ${ }^{12}$ Feedstock processing in a biorefinery consists of a mechanical fractionation process to generate a juice and a fibre fraction. The main goal of the treatment is to separate the soluble components into a liquid phase in order to leave a fibre fraction for other utilisations. ${ }^{13}$ Therefore, only soluble protein fractions such as $A, B_{1}$ and $B_{2}$ are expected to be directly extractable. However, extractability of fraction $B_{3}$, which is bound to the cell wall, may become possible by using other pre-treatment techniques such as ammonia fibre expansion (AFEX) or utilising enzymes. ${ }^{14-16}$ The protein obtained from the press juice by precipitation can be fed to non-ruminants such as pigs and poultry while

\footnotetext{
Correspondence to: Z Solati, Department of Agroecology, Aarhus University, Blichers Allé 20, 8830 Tjele, Denmark.E-mail:zeinab.solati@agro.au.dk

Some of the results were published in the proceedings of the $26^{\text {th }}$ European Grassland Federation (EGF) general meeting 'The Multiple Roles of Grassland in the European Bioeconomy', 5-8 September 2016, Trondheim, Norway

Department of Agroecology, Aarhus University, Tjele, Denmark
} 


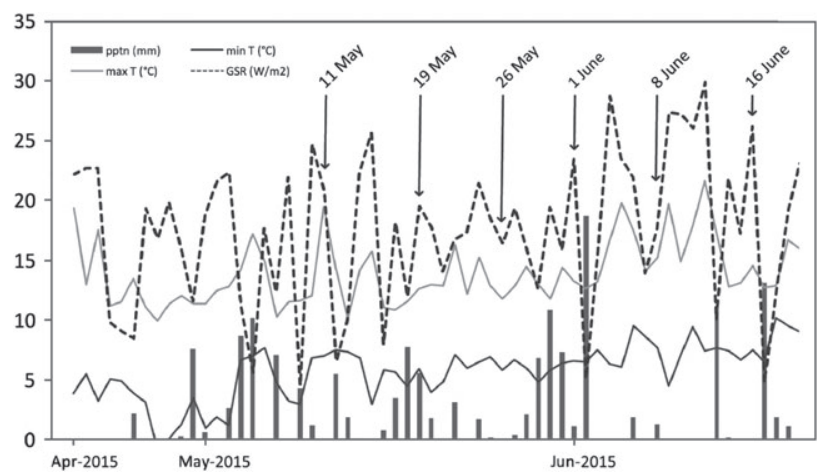

Figure 1. Minimum temperature $(\min T)$, maximum temperature $(\max T)$, precipitation (pptn), and global solar radiation (SGR) at Foulum, in spring 2015.

the press cake can be a valuable forage source for ruminants. ${ }^{17}$ The herbage cell contents decrease with maturity, $\mathrm{CP}$ being the most notable one. ${ }^{18}$ The proportion of $\mathrm{CP}$ fractions relative to total CP may also be altered with increasing maturity. The concentration of $\mathrm{CP}$ is higher in legumes and the cell wall content is lower (especially that of hemicellulose) compared with grasses. ${ }^{19}$ However, there is a shortage of thorough comparisons in the literature of legumes and grasses with regard to their relative contents of CP fractions.

The aim of this study was to investigate the change in protein fractions over a month and a half during the spring growing season in three legumes and two grasses. We hypothesised that there would be a significant effect of morphological development on protein fractions, due to decreasing content of cell content, increasing content of cell wall and increasing lignification of the cell wall. We also hypothesised that there are clear species differences, and that these differences would be reduced due to morphological changes. Concerning the functional groups (legumes vs. grasses), we hypothesised that there would be a higher content of soluble protein in legumes due to their higher CP content and lower cell wall content, and a lower $\mathrm{B}_{3}$ fraction in legumes due to a lower content of hemicellulose in legumes than in grasses.

In this study, the effect of harvest at different morphological stages and plant species on variation of CP fractions and estimated extractable protein was assessed using CNCPS.

\section{MATERIALS AND METHODS}

\section{Field experiment}

The field experiment was stablished at Aarhus University, Foulumgaard ( $\left.56^{\circ} 30^{\prime} \mathrm{N}, 9^{\circ} 35^{\prime} \mathrm{E}\right)$. The soil is classified as a Typic Hapludult, according to the USDA Soil Taxonomy System with 7\% clay, $10 \%$ silt, $81 \%$ sand and $1.7 \% \mathrm{C}$ in the topsoil $(0-20 \mathrm{~cm})$. The soil $\mathrm{pH}$ was 5.9 and concentrations of extractable $\mathrm{P}$, exchangeable $\mathrm{K}$ and exchangeable mg were 36,129 and $39 \mathrm{mg} \mathrm{kg}^{-1}$ soil, respectively.

The legume species consisted of white clover (Trifolium repens $\mathrm{L}$.), red clover (Trifolium pratense L.) and lucerne (Medicago sativa L.) and the grass species were perennial ryegrass (Lolium perenne L.) and tall fescue (Festuca arundinacea L.) undersown in a spring-barley cover crop in 2014. The cultivars studied were 'Silvester' white clover, 'Suez' red clover, 'Creno' lucerne, 'Calvan 1' perennial ryegrass and 'Tower' tall fescue. Field plots $(1.5 \times 12 \mathrm{~m})$ were arranged according to a split plot design (harvest time as main plot and species as sub-plot) with four replications. The sowing rate was $10 \mathrm{~kg} \mathrm{ha}^{-1}$ for white clover and red clover, $20 \mathrm{~kg} \mathrm{ha}^{-1}$ for lucerne, and $25 \mathrm{~kg} \mathrm{ha}^{-1}$ for the grasses. In 2014, the cover crop was harvested at maturity and one cut of the grassland species was made in mid-October. In spring 2015, grasses were fertilised with $140 \mathrm{~kg} \mathrm{~N} \mathrm{ha}^{-1}$ and both grasses and legumes were fertilised with $100 \mathrm{~kg} \mathrm{~K} \mathrm{ha}^{-1}$ in accordance with Danish fertilisation regulations.

The daily maximum and minimum temperature, precipitation and global radiation for the spring growth period are presented in Fig. 1. The legume and grass swards were harvested six times during the spring growth from 11 May to 1 June 2015. The growth stage of legume and grass species at each harvest date is presented in Table 1.

The plots were harvested at $7 \mathrm{~cm}$ stubble height using a Haldrup plot harvester (J. Haldrup a/s, Løgstør, Denmark). The time from harvesting to drying of the samples was recorded to be between 0.5 and $1 \mathrm{~h}$.

A representative sub-sample of approximately $2-3 \mathrm{~kg}$ was taken from the harvested plant material, of which a sub-sample of 200-300 g was taken for DM determination. Samples were dried at $60^{\circ} \mathrm{C}$ for $48 \mathrm{~h}$ in order to determine the DM yield. Between $50-60 \mathrm{~g}$ of dried samples were collected and ground to $1 \mathrm{~mm}$ particle size prior to the laboratory analysis using a Foss Cyclotec 1093 mill. Ground samples were stored in air tight bottles at room temperature until further analysis.

\section{Laboratory analysis}

Crude protein was fractionated into five different fractions according to CNCPS following the methods of Licitra et al. ${ }^{10} \mathrm{~A}$ minor modification was applied to the soluble protein determination assay by substituting sodium azide with ProClin 300 . Fractions $A$ and $B_{1}$ are soluble in a borate-phosphate buffer. Fraction $B_{2}$ is insoluble in a borate-phosphate buffer but soluble in a neutral detergent solvent. Fraction $B_{3}$ is insoluble in a neutral detergent solution but

Table 1. Morphological stages of legume and grass species at different harvests during the spring.

\begin{tabular}{|c|c|c|c|c|c|}
\hline Harvest date & White clover & Red clover & Lucerne & Perennial ryegrass & Tall fescue \\
\hline 11 May & Vegetative & Early vegetative & Early vegetative & Second leaf & First leaf \\
\hline 19 May & Vegetative & Early vegetative & Early vegetative & $\begin{array}{l}\text { Second node noticeable } \\
\text { or visible }\end{array}$ & $\begin{array}{l}\text { Second node noticeable } \\
\text { or visible }\end{array}$ \\
\hline 26 May & Vegetative & Mid vegetative & Mid vegetative & $\begin{array}{l}\text { Second node noticeable } \\
\text { or visible }\end{array}$ & Boot stage \\
\hline 1 June & Vegetative & Mid vegetative & Late vegetative & Boot stage & $\begin{array}{l}\text { Flowers visible/first } \\
\text { spikelets visible }\end{array}$ \\
\hline 8 June & Vegetative & Early bud & Early bud & Stem fully extended & Stem fully extended \\
\hline 16 June & $\begin{array}{l}\text { Primary } \\
\quad \text { flower buds }\end{array}$ & Early flowering & Early bud & Fully developed flowers & Fully developed flowers \\
\hline
\end{tabular}


soluble in an acid detergent solution. Fraction A was estimated by subtracting the precipitated protein using trichloroacetic acid (TCA) from total CP. Fraction $B_{1}$ was determined as the difference between the borate-phosphate buffer insoluble protein and TCA precipitated protein. Fraction $B_{3}$ was measured by the difference between acid detergent insoluble protein (ADIP) and the neutral detergent insoluble protein (NDIP). Fraction $C$ was estimated as ADIP. Fraction $B_{2}$ was calculated by the difference between the borate-phosphate insoluble protein and NDIP. All CP measurements were carried out using the Kjeldahl method with a nitrogen-to-CP conversion factor of $6.25 .{ }^{20}$ Neutral detergent fibre (aNDF) and acid detergent fibre (ADF) were determined within the $\mathrm{CP}$ fractionation procedures used to determine NDIP and ADIP and the results were expressed inclusive of the residual ash. For the NDF assay, $50 \mu \mathrm{L}$ heat-stable amylase number $\mathrm{A} 3306$ was used. ${ }^{21}$

\section{Statistical analysis}

The effects of species and harvest date on the yield, chemical composition and $\mathrm{CP}$ fractions were evaluated according to a linear mixed model using $\mathrm{R}$ statistical software. Plant species and harvest dates were fixed variables while field replication was the random variable. The following model was used: $Y_{i j k}=\mu+H_{i}+S_{j}+H S_{i j}+\delta_{i j(k)}+\varepsilon_{i j k}$, where $Y_{i j k}$ is an observation of the dependent variable, $\mu$ is the population mean for the variable, $H_{i}$ is the effect of harvest date, $S_{j}$ is the effect of species, $H S_{i j}$ is the interaction effect of harvest date and species, $\delta_{i j(k)}$ is the random effect, and $\varepsilon_{i j k}$ is the random error associated with the observation.

$\delta_{i j(k)} \sim N\left(0, \delta_{1}\right), \varepsilon_{i j k} \sim N\left(0, \delta_{2}\right)$, and $\delta_{1}+\delta_{2}$ are independent. The difference between the mean values was determined by Tukey's HSD test. The significance of the change in the proportion of individual $C P$ fractions during spring growth was examined using a simple linear regression model as follows: $Y=a X+b$, where $Y$ is the proportion of CP fractions, $X$ is the maturity stage which was expressed as the number of days after the first harvest and $a$ and $b$ are constants. Unless otherwise specified, a probability of $P<0.05$ was considered significant.

\section{RESULTS}

\section{Dry matter yield and chemical composition}

The significance of the effects of plant species, maturity and their interaction on DM yield and chemical composition is presented in Table 2 . The yield results presented here only cover early harvest and not annual yields. There was a significant increase in the yield of all the species from first to the last harvest with the highest yield of the grass species on the last harvest whereas the yield of legume species levelled off and did not increase significantly afterwards (Fig. 2A).

There was a significant decline in $\mathrm{CP}$ content of all the species across the spring growth (Fig. 2B). A larger decline in $\mathrm{CP}$ with increasing maturity was observed for grass species compared with legumes. Legumes contained significantly higher amounts of $\mathrm{CP}$ across the harvests compared to grasses. Of all the species, white clover had a significantly higher $\mathrm{CP}$ content which varied between $292 \mathrm{~g} \mathrm{~kg}^{-1} \mathrm{DM}$ at the first harvest and $214 \mathrm{~g} \mathrm{~kg}^{-1} \mathrm{DM}$ at the last harvest.

The aNDF content increased significantly from the first to the last harvest in all legume and grass species, whereas the highest increase in aNDF (108\%) was observed for lucerne from the first to the last harvest (Fig. 2C). Although legume species showed a higher increase in aNDF content from the first to the last harvest, 
(A)



(C)

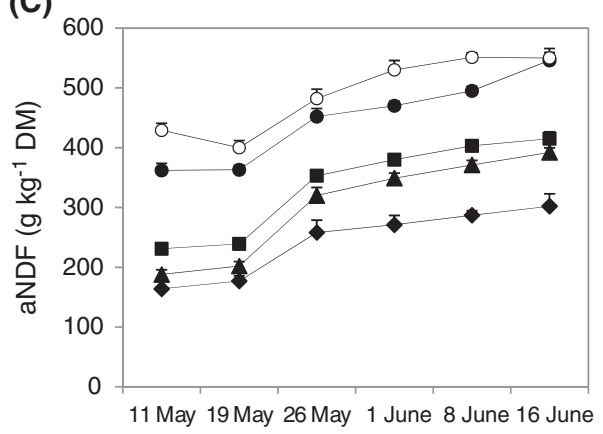

(B)

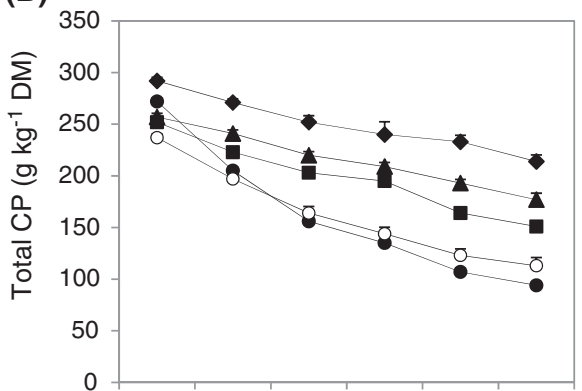

(D)

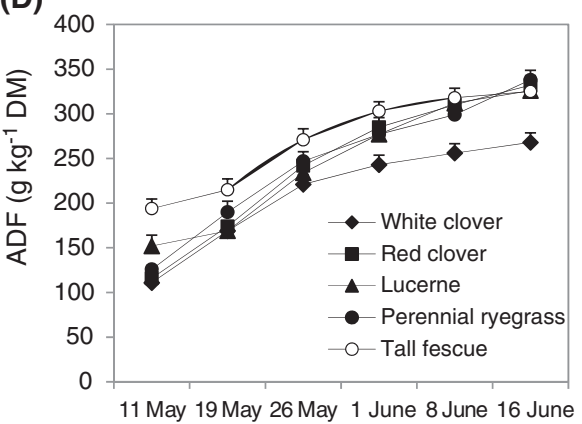

Figure 2. Dry matter yield (A), CP content (B), aNDF (C), and ADF (D) in legume and grass species across the harvets during the spring growth. Data represent least square means and standard error.

the amount of aNDF was significantly higher in grasses compared with legumes at all harvests. The ADF content was more affected by maturity than by plant species and increased significantly from the first to the last harvest (Fig. 2D). White clover had a significantly lower aNDF and ADF compared with other species at late harvests.

\section{Crude protein fractions}

The significance levels from the analysis of variance for $\mathrm{CP}$ fractions based on total CP are presented in Table 2.

\section{Fraction A}

Generally, on a CP basis, legumes had a significantly higher accumulation of fraction A compared with the grass species, except for the first and last harvests (Fig. 3A). A significant increase in fraction $A$ across the spring growth was only observed for white clover. Relative to DM content, fraction A ( $\mathrm{g} \mathrm{kg}^{-1} \mathrm{DM}$ ) decreased significantly in red clover and grass species across the spring growth (Table 3).

\section{Fraction $B$}

Fraction $B_{1}$ relative to $C P\left(\mathrm{~g} \mathrm{~kg}^{-1} \mathrm{CP}\right)$ showed a significant decrease across the harvests in white clover, lucerne, and perennial ryegrass (Fig. 3B). At the first harvest, a significantly lower $B_{1}$ was noted for legume species with the exception of lucerne. As maturity progressed during the spring growth period less variation was observed among legumes and grasses up to the third harvest, and at the last harvest there was no inter-species difference. Relative to the DM content, a significant decline was observed in the $B_{1}$ fraction $\left(\mathrm{g} \mathrm{kg}^{-1} \mathrm{DM}\right)$ with increasing maturity in all the species, except for red clover (Table 3 ). The size of fraction $B_{1}$ relative to DM was affected more by maturity than by plant species.

Relative to $C P$, fraction $B_{2}$ was the largest fraction and it was highly affected by the plant species with especially a lower content in red clover. $A$ significant decline in fraction $B_{2}\left(\mathrm{~g} \mathrm{~kg}^{-1} \mathrm{CP}\right)$ was observed in white clover and lucerne across the spring growth (Fig. 3C). Relative to DM content, fraction $B_{2}$ declined significantly in all the species with increasing maturity (Table 3 ).

Relative to $C P$, the trend for change in fraction $B_{3}$ across the spring growth was not significant in any of the species (Fig. 3D). Red clover contained most $B_{3}$ at all harvests whilst lucerne had significantly less $B_{3}$ at most of the harvests. In contrast to our hypothesis, we observed a significantly larger $B_{3}$ (despite significantly less aNDF compared with grasses) fraction in red clover compared with grass species. Relative to DM content ( $\left.\mathrm{g} \mathrm{kg}^{-1} \mathrm{DM}\right)$, fraction $B_{3}$ declined significantly only in red clover and perennial ryegrass across the spring growth. Red clover had significantly more $B_{3}$ across all the harvests compared with other species (Table 3 ).

\section{Fraction $C$}

Relative to $\mathrm{CP}\left(\mathrm{g} \mathrm{kg}^{-1} \mathrm{CP}\right)$, a significant increase in fraction $\mathrm{C}$ was observed for red clover, lucerne and tall fescue across the spring growth (Fig. 3E). Relative to DM content, a significant increase in fraction $\mathrm{C}$ was observed only in red clover with increasing maturity (Table 3). Grasses contained significantly less fraction $C$ at most of the harvests compared with the legume species.

\section{Estimated extractable protein}

The potentially extractable true protein amount was defined as $B_{1}+B_{2}$ and as $B_{1}+B_{2}+B_{3}$ in case fraction $B_{3}$ can be extracted too and was expressed based on $\mathrm{g} \mathrm{kg}^{-1} \mathrm{CP}, \mathrm{g} \mathrm{kg}^{-1} \mathrm{DM}$ and $\mathrm{kg} \mathrm{ha}^{-1}$ in Fig. 4. The significance levels from the analysis of variance for extractable protein amount are presented in Table 2.

The extractable protein fraction $\mathrm{B}_{1}+\mathrm{B}_{2}\left(\mathrm{~g} \mathrm{~kg}^{-1} \mathrm{CP}\right)$ significantly declined across the spring growth in all the species except in red clover, which was always at a lower level than the other species (Fig. 4A). Relative to DM content, extractable protein significantly decreased across the spring growth in all the species (Fig. 4C). White clover had a significantly higher $B_{1}+B_{2}$ protein at the 
(A)

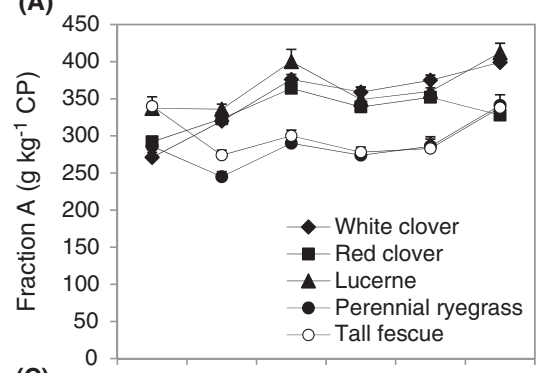

(C) 600
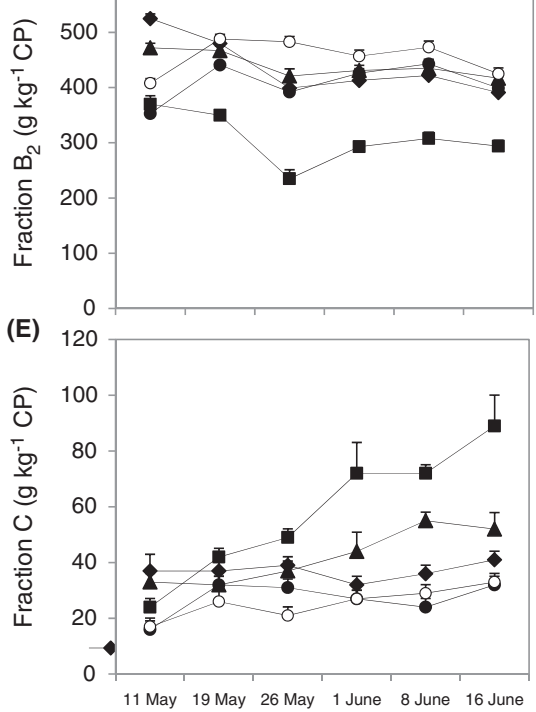

(B) 200

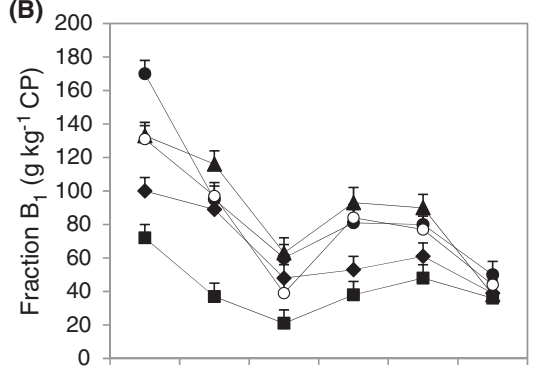

(D) 400

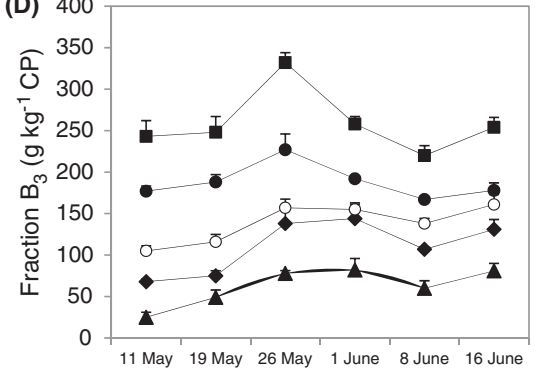

Figure 3. Crude protein fractions in legume and grass species across the harvests during the spring growth. Data represent least square means and standard error.

first two harvests (182 and $154 \mathrm{~g} \mathrm{~kg}^{-1} \mathrm{DM}$, respectively), while from the third harvest onward white clover shared that position with lucerne. Estimated extractable protein per ha significantly increased with increasing maturity in all the species except in red clover (Fig. 4E). White clover and red clover had a significantly higher extractable protein content per ha at the first two harvests compared with the other species.

Estimated extractable protein $\left(\mathrm{g} \mathrm{kg}^{-1} \mathrm{CP}\right)$ defined as $\mathrm{B}_{1}+\mathrm{B}_{2}+\mathrm{B}_{3}$ significantly declined in white clover and red clover and tended to decline in lucerne across the spring growth (Fig. 4B). Grass species had significantly more extractable protein than legumes from the second harvest onward. Relative to DM content, extractable protein significantly declined in all the species with increasing maturity (Fig. 4D). White clover had by far the highest $B_{1}+B_{2}+B_{3}$ protein content from the second harvest onward (ranging from 174 to $120 \mathrm{~g} \mathrm{~kg}^{-1}$ DM). Extractable protein per ha significantly increased in lucerne and grass species with increasing maturity and was by far the highest in red clover (ranging between 514 and $726 \mathrm{~kg} \mathrm{ha}^{-1}$ ) at all harvests (Fig. 4F).

\section{DISCUSSION}

\section{Dry matter yield and chemical composition}

This study only covered the development across the spring cut date for grasses and legumes, and two or more cuts are expected over the whole season. Thus, a total DM yield of up to 6-8 ton $\mathrm{ha}^{-1}$ in the grasses and in red clover indicates a high productivity. The pattern in DM accumulation of legume and grass species with increasing maturity is important for proper timing of the harvest, where even though delaying the harvest will increase the DM yield of the crop significantly, the quality, i.e. the CP content in the DM, will decline.

The decline in $\mathrm{CP}$ concentration with increasing maturity reflects the alterations in $\mathrm{CP}$ fractions and thus soluble protein content as the plant matures. Accordingly, harvest date has a great importance if we are to achieve the highest protein production potential in a biorefinery. Alzueta et al. ${ }^{7}$ similarly reported a decreasing trend in $\mathrm{CP}$ content of a common vetch forage crop over two seasons as the plant matured beyond flowering. $A$ notable decline in $C P$ content was observed by Givens et al. ${ }^{18}$ in spring-grown herbage with increasing maturity. The reduction in $\mathrm{CP}$ with maturity could be caused by the decrease in the proportion of leaves that contain higher amount of protein..$^{22}$ Our observation of a significantly higher amount of CP in legumes than in grasses agreed with the study by Sanderson and Wedin ${ }^{23}$ and our finding of a significantly lower CP content in red clover compared with other legume species agrees with the study of Hoffman et al., ${ }^{24}$ who observed a significantly lower CP content in red clover compared with lucerne.

The chemical composition and structure of cell walls in legume and grass species may affect the protein extraction as pre-treatment techniques that alter the cell wall structure resulted in enhanced protein extraction yields. ${ }^{25}$ The increase in aNDF with advancing maturity is probably a result of changes in the composition of the cell wall with maturity. ${ }^{26}$ Grasses contain more NDF compared with legumes, which is mostly due to differences in the NDF contents between grass and legume leaves. ${ }^{27}$ 
Table 3. Concentrations of $\mathrm{CP}$ fractions $\left(\mathrm{g} \mathrm{kg}^{-1} \mathrm{DM}\right)$ at different harvests during the spring.

CP fractions ( $\left.\mathrm{g} \mathrm{kg}^{-1} \mathrm{DM}\right)$

\begin{tabular}{|c|c|c|c|c|c|c|}
\hline \multirow{2}{*}{\multicolumn{2}{|c|}{ Species }} & \\
\hline & & $A$ & $\mathrm{~B}_{1}$ & $\mathrm{~B}_{2}$ & $\mathrm{~B}_{3}$ & $C$ \\
\hline \multirow[t]{6}{*}{ White clover } & 11 May & $79^{\mathrm{a}, \mathrm{AB}}$ & $29^{b, B}$ & $153^{d, C}$ & $20^{a b, B}$ & $11^{\mathrm{a}, \mathrm{c}}$ \\
\hline & 19 May & $87^{a b, c}$ & $24^{\mathrm{b}, \mathrm{BC}}$ & $130^{c, D}$ & $20^{\mathrm{a}, \mathrm{B}}$ & $10^{\mathrm{a}, \mathrm{B}}$ \\
\hline & 26 May & $95^{\mathrm{b}, \mathrm{c}}$ & $12^{\mathrm{a}, \mathrm{BC}}$ & $100^{\mathrm{b}, \mathrm{D}}$ & $35^{\mathrm{b}, \mathrm{BC}}$ & $10^{a, c}$ \\
\hline & 1 Jun & $86^{a b, c}$ & $13^{\mathrm{a}, \mathrm{AB}}$ & $100^{\mathrm{b}, \mathrm{B}}$ & $34^{\mathrm{ab}, \mathrm{B}}$ & $8^{\mathrm{a}, \mathrm{B}}$ \\
\hline & 8 Jun & $87^{\mathrm{ab}, \mathrm{D}}$ & $14^{\mathrm{a}, \mathrm{AB}}$ & $98^{b, D}$ & $25^{b, c}$ & $8^{a, B}$ \\
\hline & 16 Jun & $85^{\mathrm{ab}, \mathrm{D}}$ & $8^{\mathrm{a}, \mathrm{A}}$ & $84^{\mathrm{a}, \mathrm{C}}$ & $28^{\mathrm{ab}, \mathrm{B}}$ & $9^{a, B}$ \\
\hline \multirow[t]{6}{*}{ Red clover } & 11 May & $73^{\mathrm{d}, \mathrm{A}}$ & $18^{\mathrm{b}, \mathrm{A}}$ & $93^{\mathrm{c}, \mathrm{A}}$ & $61^{b c, c}$ & $6^{\mathrm{a}, \mathrm{AB}}$ \\
\hline & 19 May & $72^{\mathrm{cd}, \mathrm{B}}$ & $8^{\mathrm{a}, \mathrm{A}}$ & $78^{\mathrm{b}, \mathrm{A}}$ & $55^{\mathrm{bc}, \mathrm{D}}$ & $9^{a b c, B}$ \\
\hline & 26 May & $74^{\mathrm{cd}, \mathrm{B}}$ & $4^{\mathrm{a}, \mathrm{A}}$ & $48^{\mathrm{a}, \mathrm{A}}$ & $67^{C, D}$ & $10^{b, c}$ \\
\hline & 1 Jun & $66^{\mathrm{bc}, \mathrm{B}}$ & $7^{\mathrm{a}, \mathrm{A}}$ & $57^{\mathrm{a}, \mathrm{A}}$ & $50^{b, c}$ & $14^{\mathrm{c}, \mathrm{C}}$ \\
\hline & 8 Jun & $58^{\mathrm{ab}, \mathrm{B}}$ & $8^{\mathrm{a}, \mathrm{A}}$ & $50^{\mathrm{a}, \mathrm{AB}}$ & $36^{\mathrm{a}, \mathrm{D}}$ & $12^{\mathrm{bc}, \mathrm{c}}$ \\
\hline & 16 Jun & $50^{\mathrm{a}, \mathrm{B}}$ & $5^{\mathrm{a}, \mathrm{A}}$ & $44^{\mathrm{a}, \mathrm{AB}}$ & $39^{\mathrm{aC}}$ & $13^{b c, c}$ \\
\hline \multirow[t]{6}{*}{ Lucerne } & 11 May & $87^{c, B}$ & $34^{c, B}$ & $121^{C, B}$ & $6^{\mathrm{a}, \mathrm{A}}$ & $8^{\mathrm{a}, \mathrm{BC}}$ \\
\hline & 19 May & $81^{b c, c}$ & $28^{c, C}$ & $112^{c, C}$ & $12^{\mathrm{ab}, \mathrm{A}}$ & $8^{a, A B}$ \\
\hline & 26 May & $90^{b c, c}$ & $14^{a b, c}$ & $93^{b, D}$ & $18^{\mathrm{ab}, \mathrm{A}}$ & $8^{\mathrm{aBC}}$ \\
\hline & 1 Jun & $72^{\mathrm{abc}, \mathrm{BC}}$ & $19^{b, B}$ & $89^{b, B}$ & $17^{\mathrm{abc}, \mathrm{A}}$ & $9^{a, B}$ \\
\hline & 8 Jun & $69^{\mathrm{a}, \mathrm{c}}$ & $17^{b, B}$ & $84^{a b, c}$ & $12^{\mathrm{ab}, \mathrm{A}}$ & $11^{\mathrm{a}, \mathrm{BC}}$ \\
\hline & 16 Jun & $73^{a b, c}$ & $7^{\mathrm{a}, \mathrm{A}}$ & $74^{\mathrm{a}, \mathrm{c}}$ & $14^{\mathrm{bc}, \mathrm{A}}$ & $9^{a, B}$ \\
\hline \multirow[t]{6}{*}{ Perennial ryegrass } & 11 May & $78^{\mathrm{d}, A B}$ & $46^{c, C}$ & $96^{\mathrm{d}, \mathrm{A}}$ & $48^{\mathrm{d}, \mathrm{C}}$ & $4^{\mathrm{ab}, \mathrm{A}}$ \\
\hline & 19 May & $50^{\mathrm{c}, \mathrm{A}}$ & $19^{\mathrm{b}, \mathrm{B}}$ & $90^{\mathrm{d}, \mathrm{B}}$ & $38^{\mathrm{cd}, \mathrm{C}}$ & $7^{b, A B}$ \\
\hline & 26 May & $45^{\mathrm{bc}, \mathrm{A}}$ & $9^{\mathrm{a}, \mathrm{ABC}}$ & $61^{c, B}$ & $36^{c, C}$ & $5^{\mathrm{b}, \mathrm{AB}}$ \\
\hline & 1 Jun & $37^{\mathrm{ab}, \mathrm{A}}$ & $11^{\mathrm{a}, \mathrm{A}}$ & $58^{\mathrm{bc}, \mathrm{A}}$ & $26^{\mathrm{b}, \mathrm{B}}$ & $4^{\mathrm{ab}, \mathrm{A}}$ \\
\hline & 8 Jun & $31^{a, A}$ & $9^{\mathrm{a}, \mathrm{A}}$ & $47^{\mathrm{ab}, \mathrm{A}}$ & $18^{\mathrm{a}, \mathrm{B}}$ & $3^{\mathrm{a}, \mathrm{A}}$ \\
\hline & 16 Jun & $32^{\mathrm{a}, \mathrm{A}}$ & $5^{\mathrm{a}, \mathrm{A}}$ & $37^{a, A}$ & $17^{\mathrm{a}, \mathrm{A}}$ & $3^{\mathrm{a}, \mathrm{A}}$ \\
\hline \multirow[t]{6}{*}{ Tall fescue } & 11 May & $81^{d, A B}$ & $31^{c, B}$ & $97^{\mathrm{d}, \mathrm{A}}$ & $25^{\mathrm{b}, \mathrm{B}}$ & $4^{\mathrm{a}, \mathrm{A}}$ \\
\hline & 19 May & $54^{\mathrm{c}, \mathrm{A}}$ & $19^{b, B}$ & $96^{\mathrm{d}, \mathrm{B}}$ & $23^{b, B}$ & $5^{\mathrm{a}, \mathrm{A}}$ \\
\hline & 26 May & $47^{\mathrm{bc}, \mathrm{A}}$ & $6^{\mathrm{a}, \mathrm{AB}}$ & $75^{c, C}$ & $25^{\mathrm{b}, \mathrm{B}}$ & $3^{\mathrm{a}, \mathrm{A}}$ \\
\hline & 1 Jun & $40^{\mathrm{ab}, \mathrm{A}}$ & $12^{\mathrm{ab}, \mathrm{AB}}$ & $65^{\mathrm{bc}, \mathrm{A}}$ & $22^{\mathrm{ab}, \mathrm{AB}}$ & $4^{\mathrm{a}, \mathrm{A}}$ \\
\hline & 8 Jun & $35^{a, A}$ & $10^{\mathrm{a}, \mathrm{A}}$ & $58^{\mathrm{ab}, \mathrm{B}}$ & $17^{a, B}$ & $4^{\mathrm{a}, \mathrm{A}}$ \\
\hline & 16 Jun & $38^{\mathrm{ab}, \mathrm{A}}$ & $5^{\mathrm{a}, \mathrm{A}}$ & $48^{\mathrm{a}, \mathrm{B}}$ & $18^{\mathrm{ab}, \mathrm{A}}$ & $4^{\mathrm{a}, \mathrm{A}}$ \\
\hline \multicolumn{7}{|l|}{ Significance } \\
\hline Species (S) & & $<0.001$ & $<0.001$ & $<0.001$ & $<0.001$ & $<0.001$ \\
\hline Maturity (M) & & $<0.001$ & $<0.001$ & $<0.001$ & $<0.001$ & 0.43 \\
\hline $\mathrm{S} \times \mathrm{M}$ & & $<0.001$ & $<0.001$ & $<0.001$ & $<0.001$ & $<0.001$ \\
\hline SEM & & 5.08 & 3.38 & 5.37 & 4.91 & 1.77 \\
\hline
\end{tabular}

$\mathrm{a}, \mathrm{b}, \mathrm{c}, \mathrm{d}$ Results within a column without a common letter show significant $(P<0.05)$ differences between the means at different harvests for individual species.

$A, B, C, D$ Results with different letters show significant difference among the species at different harvests.

According to Buxton, ${ }^{27}$ lucerne and most of the legume species have an ADF content that is $100 \mathrm{~g} \mathrm{~kg}^{-1}$ lower than NDF, while this difference is $200 \mathrm{~g} \mathrm{~kg}^{-1}$ for grass species.

\section{Crude protein fractions: effects of species and morphological development}

To assess the proportion of individual CP fractions is essential for determination of protein solubility and thus its potential extraction in the biorefinery. The compartmentation of protein across the later harvest was more allocated to $A, B_{3}$ and $C$ fractions, which are the least valuable for extraction compared to $B_{1}$ and $B_{2}$.

In a study by Krawutschke et al. ${ }^{28}$ a significant increase was observed in fraction A for red clover during the spring growth which was in contrast to our finding of no significant change.
Other studies claim that the size of fraction $A$ is not affected by plant maturity in the spring season. ${ }^{6,29}$ The discrepancy in changes in fraction A across the growing period between studies may be explained by different environmental conditions such as the supply of mineral $\mathrm{N}$, water stress and soil acidity. ${ }^{28}$ Our data pertaining to a higher accumulation of fraction $A$ in legumes than in grasses is supported by the study of Yu et al. ${ }^{9}$ who observed a higher fraction A content for alfalfa than for timothy (415 vs. $165 \mathrm{~g} \mathrm{~kg}^{-1} \mathrm{CP}$ ). This is probably due to the different nitrogen (N) metabolism of $\mathrm{N}$-fixing and non-N-fixing plants. ${ }^{30}$ The significantly higher fraction A content in legumes compared to grass species across most of the harvests was consistent with significantly higher $\mathrm{CP}$ contents in legumes than in grasses. The study by Krawatschke et al. ${ }^{28}$ also described a positive correlation between the total $\mathrm{N}$ yield and the fraction A content of legume species during the spring growth.

The noted decline in fraction $B_{1}$ relative to total $C P$ across the harvests may be a result of an increase in cell wall-bound proteins with maturity. ${ }^{31}$ The similar trend of a change in the $B_{1}$ fraction for all the species across the spring growth may be related to both morphological development and environmental factors. According to Buxton, ${ }^{27}$ temperature and solar radiation are some of the most important environmental factors with temperature having the greatest impact on forage quality of which protein quality is an important element. Many environmental factors affect the rate of phenological development, but during the spring growth when the water supply is ample, temperature has the greatest influence. ${ }^{32}$ Nevertheless, we could not detect any clear correlation between the temperature and changes in the $B_{1}$ fraction. In line with our observation, Hoffman et al. ${ }^{24}$ found less fractions $A$ and $B_{1}$ in red clover than in lucerne across three maturity stages.

In accordance with our results, Elizalde et al..$^{29}$ also found fraction $B_{2}$ to be the largest $C P$ fraction in forages during the spring. Our results pertaining to a significant decline in fractions $B_{1}$ and $B_{2}$ across the harvests in white clover and lucerne contradict the results of Kirchhof et al., ${ }^{6}$ who stated that plant maturity does not affect the aforementioned fractions in legume species.

Elizalde et al. ${ }^{29}$ noted that the increase in fraction $B_{3}$ with increasing maturity was consistent with the higher NDF content with maturity in lucerne, but they found no relationship between $B_{3}$ and NDF contents in grass species. The larger fraction $B_{3}$ in grasses compared with legumes in our study correlated well with a high NDF content in these species. Our data were consistent with Elizalde et al. ${ }^{29}$ who showed that fraction $\mathrm{B}_{3}$ was significantly smaller in lucerne than in grasses and that grasses had four to six times more $B_{3}$ compared with lucerne.

The high $\mathrm{B}_{3}$ concentration in freeze-dried samples of red clover compared with other legume species (i.e. white clover, lucerne, etc.) in the study by Kirchhof et al. ${ }^{6}$ was attributed to the polyphenol oxidase (PPO) activity in red clover. Weiher et al. ${ }^{33}$ concluded that oven-drying contributes to the larger size of fraction $B_{3}$ in red clover when compared with freeze-drying. Grabber ${ }^{34}$ reported $B_{3}$ values of 68 and $137 \mathrm{~g} \mathrm{~kg}^{-1} \mathrm{CP}$ for freeze-dried lucerne and red clover, respectively. Compared to the values in our study, it was similar for lucerne ( $69 \mathrm{~g} \mathrm{~kg}^{-1}$ CP on average across the harvests), but was less than half that for oven-dried red clover at its peak level of $332 \mathrm{~g} \mathrm{~kg}^{-1} \mathrm{CP}$. We speculate that this may be related to the handling of sample material prior to drying which may have resulted in the formation of quinones and subsequent formation of quinone-protein complexes. This result indicates that harvest and storage conditions for extraction of protein from red clover could be critical for a commercial operation in a green biorefinery. 

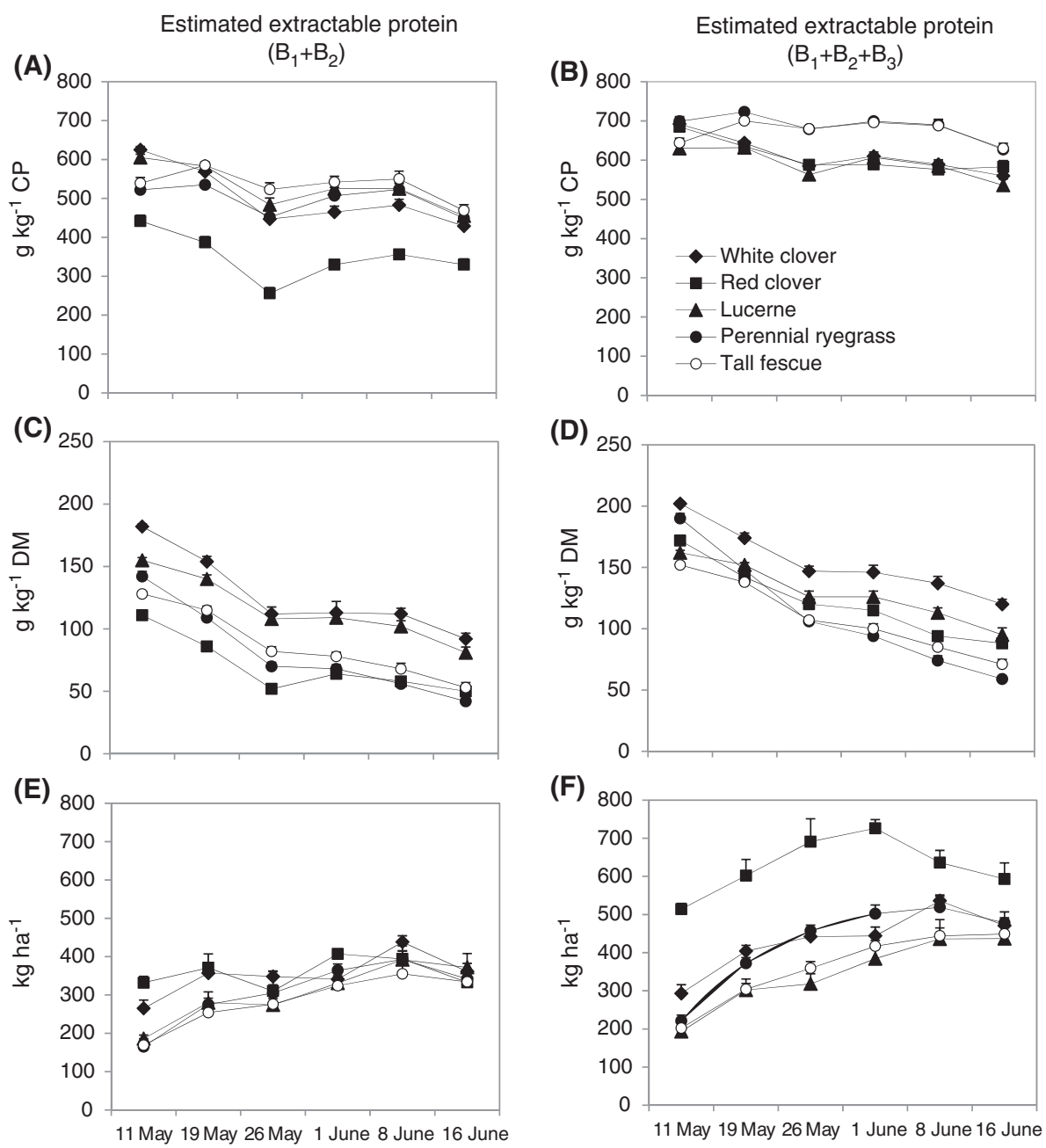

Figure 4. Estimated extractable protein defined as $B_{1}+B_{2}$ (left side shown with letters $A, C, E$ ) and $B_{1}+B_{2}+B_{3}$ (right side shown with letters $B, D$, $F$ ) in legume and grass species across the harvests during the spring growth. Data represent least square means and standard error.

In line with Kirchhof et al. ${ }^{6}$ we noticed a greater increase in fraction $C$ in red clover with increasing maturity. Sanderson and Wedin ${ }^{23}$ reported that the fraction $C$ increased with advancing maturity in red clover, lucerne, timothy and brome grass as a result of a general decline in CP and increase in ADF with increasing maturity. Significantly larger $C$ fractions in legumes compared with grass species was also noted by Sanderson and Wedin. ${ }^{23}$ This is probably due to higher lignin concentrations in legumes compared with grasses. ${ }^{24,35}$ Accordingly, higher ADF contents of legume species, especially for the last harvest dates (where legumes showed significantly larger $C$ fractions compared with grasses), were expected since the ADF residue is used for determination of fraction C. Nevertheless, an earlier study by Machacek and Konnonoff ${ }^{36}$ showed that ADF content is poorly related to fraction $C$ content and thus is not appropriate for such prediction. Sanderson and Wedin ${ }^{23}$ stated that factors other than or including the lignin content may contribute to the size of fraction C.

Despite the stage of maturity was reported to greatly influence the quality of forage, ${ }^{27}$ we observed less variation in CP fractions as affected by maturity than by plant species, although the harvest of species was performed over a long growing period where great phenological changes take place for individual species.

\section{The estimated extractable protein and its implication}

Expression of the extractable protein as $\mathrm{g} \mathrm{kg}^{-1} \mathrm{CP}, \mathrm{g} \mathrm{kg}^{-1} \mathrm{DM}$ and $\mathrm{kg} \mathrm{ha}^{-1}$ revealed different results when comparing different plant species. Extractable protein based on $\mathrm{g} \mathrm{kg}^{-1} \mathrm{CP}$ is the traditional way of presenting the results for use in evaluation of forage feed quality. ${ }^{37}$ For biorefinery purposes, displaying the extractable protein in $\mathrm{g} \mathrm{kg}^{-1} \mathrm{DM}$ may be more relevant as the protein content per unit mass is of huge importance for logistics and design of equipment in terms of capacity and perhaps mobility. Finally, expressing the extractable protein in $\mathrm{kg} \mathrm{ha}^{-1}$ is of economic importance to the farmers.

The significantly larger amount $\left(\mathrm{kg} \mathrm{ha}^{-1}\right)$ of extractable protein $\left(B_{1}+B_{2}+B_{3}\right)$ in red clover across all harvests was consistent with the significantly high DM yield for most of the harvests during the spring. Especially at early harvests extractable protein is already high in red clover, and after cutting early an early regrowth can be achieved.

In agreement with our results, McKenzie ${ }^{38}$ observed a remarkable decrease in protein extractability of grasses with increasing maturity. A trend for extracted protein yields to decrease with increasing maturity was also observed by Nanda et al. ${ }^{39}$ which was attributed to the increase in the density of the cell wall material. The lower extractable protein content $\left(\mathrm{g} \mathrm{kg}^{-1} \mathrm{DM}\right)$ in grasses compared with legumes was expected from the significantly lower 
protein content in grasses, despite their significantly higher DM yield. The possibility of achieving high protein yields by using the ammonia fibre expansion (AFEX) pre-treatment method which intensively disrupts the cell has previously been reported. ${ }^{40-42} \mathrm{~A}$ further increase in the yield of extracted protein was reported by Luis et $a .^{40}$ using cellulase to hydrolyse the cellulose. Dotsenko and Lange ${ }^{16}$ were able to extract approximately $80 \%$ of the remaining protein in the pulp fraction of white clover and perennial ryegrass using proteases. Therefore, the extraction of fraction $B_{3}$ is expected to be facilitated by using the pre-treatment techniques.

Allocation of protein to the least valuable fractions for extraction $\left(A, B_{3}\right.$ and $\left.C\right)$ at the last harvest indicates that taking the cut at the fourth harvest time might be the most optimal in practice, as total extractable protein per ha only increased slightly (and only if $B_{3}$ can also be extracted) after then or even an earlier cut may be most beneficial, as it would allow for more cuts across the whole season.

The final choice of optimal species and harvest time will depend on the value created from each fraction of the feedstock in the biorefinery, and not just the protein. The fibre fraction seems to be a valuable cattle feed that may be used locally if decentralised biorefineries are established. But it may also be further refined into chemicals or energy products such as HTL bio-oil (Johannsen, http://dca.au.dk/en) or biogas. ${ }^{43}$ Thus, it is a complex calculation to decide which species and cutting time will provide the most profit in the process, and it will probably be an individual decision between specific biorefinery set-ups, and over time, as product portfolios develop. If protein is the most desired and profitable component to be extracted, it seems that legumes will provide the best feedstock quality, especially when harvested early. White clover showed the highest content of extractable fractions per $\mathrm{kg} \mathrm{DM}$, and has been shown to give high total yields with many cuts. ${ }^{44}$ However, if red clover can be managed without too much quinone formation that hampers the protein solubility, it seems to be able to provide very high total amounts of protein per ha already by early harvest, which can contribute to a good overall business economy.

\section{CONCLUSIONS}

This study provides a thorough comparison of legume and grass species in terms of DM yield, chemical composition and extractable protein amount across the spring growth. The results showed superiority of white clover and lucerne to grasses including perennial ryegrass and tall fescue with regard to extractable protein per kg DM. However, extractable protein amount in perennial ryegrass showed promise at the start of growing season in case fraction $\mathrm{B}_{3}$ can be extracted. The final choice of species and harvest time for a given biorefinery will depend strongly on the end use of the other products of the refinery process and logistics of the production chain as well as the regrowth potential over the remaining growing season for each species. Although extractability of protein per ha increased in especially lucerne and grass species with increasing maturity, delaying the harvest time was plainly detrimental to extractable protein amount on a DM basis.

\section{ACKNOWLEDGEMENTS}

This study was funded by the BioValue SPIR, Strategic Platform for Innovation and Research on value added products from biomass, which is co-funded by The Innovation Fund Denmark, case no: $0603-00522 B$. The authors would like to thank Sanmohan Santhome for his statistical advice.

\section{REFERENCES}

1 Van Krimpen MM, Bikker P, Van der Meer IM, Van der Peet-Schwering CM and Vereijken JM, Cultivation, Processing and Nutritional Aspects for Pigs and Poultry of European Protein Sources as Alternatives for Imported Soybean Products. Wageningen UR Livestock Production Report 662:1-3 (2013).

2 Houseman RA and Connel J, Utilization of products of green-crop fractionation by pigs and ruminants. Proc Nutr Soc 35:213-220 (1976).

3 Fornara DA and Tilman D, Plant functional composition influences rates of soil carbon and nitrogen accumulation. J Ecol 96:314-322 (2008).

4 Eisenhauer N, Milcu A, Sabais AC, Bessler H, Weigelt A, Engels C et al., Plant community impacts on the structure of earthworm communities depend on season and change with time. Soil Biol Biochem 41:2430-2443 (2009).

5 Pugesgaard S, Schelde K, Larsen SU, Lærke PE and Jørgensen U, Comparing annual and perennial crops for bioenergy production - influence on nitrate leaching and energy balance. GCB Bioenergy 7:1136-1149 (2015).

6 Kirchhof S, Eisner I, Gierus M and Südekum KH, Variation in the contents of crude protein fractions of different forage legumes during the spring growth. Grass Forage Sci 65:376-382 (2010).

7 Alzueta C, Caballero R, Rebole A, Trevino J and Gil A, Crude protein fractions in common vetch (Vicia sativa L.) fresh forage during pod filling. J Anim Sci 79:2449-2455 (2001).

8 Abbasi D, Rouzbehan Y and Rezaei J, Effect of harvest date and nitrogen fertilization rate on the nutritive value of amaranth forage (Amaranthus hypochondriacus). Anim Feed Sci Technol 171:6-13 (2012).

9 Yu P, Christensen DA, McKinnon JJ and Markert JD, Effect of variety and maturity stage on chemical composition, carbohydrate and protein subfractions, in vitro rumen degradability and energy values of timothy and alfalfa. Can J Anim Sci 83:279-290 (2003).

10 Licitra G, Hernandez TM and Van Soest PJ, Standardization of procedures for nitrogen fractionation of ruminant feeds. Anim Feed Sci Technol 57:347-358 (1996).

11 Ecker J, Schaffenberger M, Koschuh W, Mandl M, Böchzelt HG, Schnitzer $\mathrm{H}$ et al., Green biorefinery upper Austria-pilot plant operation. Sep Purif Technol 96:237-247 (2012).

12 Lammens TM, Franssen MC, Scott EL and Sanders JP, Availability of protein-derived amino acids as feedstock for the production of bio-based chemicals. Biomass Bioenergy 44:168-181 (2012).

13 Mandl MG, Status of green biorefining in Europe. Biofuels Bioprod Biorefin 4:268-274 (2010).

14 Bals B, Teachworth L, Dale B and Balan V, Extraction of proteins from switchgrass using aqueous ammonia within an integrated biorefinery. Appl Biochem Biotechnol 143:187-198 (2007).

15 Sari YW, Bruins ME and Sanders JP, Enzyme assisted protein extraction from rapeseed, soybean, and microalgae meals. Indust Crop Product 43:78-83 (2013).

16 Dotsenko $G$ and Lange L, Enzyme enhanced protein recovery from green biomass pulp. Waste Biomass Valoriz 1 -8 (2016).

17 Jones AS, The principles of green crop fractionation, in Proceedings of the Occasional Symposium of British Society of Animal Production (Wilkins RJ Ed.), 25-26 Nov., Harrogate, British Grassland Society 9:1-7 (1977).

18 Givens DI, Everington JM and Adamson $\mathrm{AH}$, The nutritive value of spring-grown herbage produced on farms throughout England and Wales over four years. I. The effect of stage of maturity and other factors on chemical composition, apparent digestibility and energy values measured in vivo. Anim Feed Sci Technol 27:157- 172 (1989).

19 Thomas C, Chamberlain DG, Wiseman J and Cole DJ, Evaluation and prediction of the nutritive value of pastures and forages. Feedstuff Evaluation 319-336 (1990).

20 Association of Official Analytical Chemists (AOAC), Official Methods of Analysis, 18th edition. AOAC International, Arlington, VA (2005).

21 Van Soest PV, Robertson JB and Lewis BA, Methods for dietary fiber, neutral detergent fiber, and nonstarch polysaccharides in relation to animal nutrition. J Dairy Sci 74:3583-3597 (1991).

22 Freer M and Dove H (eds), Sheep Nutrition. CABI, Wallingford, UK (2002).

23 Sanderson MA and Wedin WF, Nitrogen in the detergent fiber fractions of temperate legumes and grasses. Grass Forage Sci 44:159-168 (1989).

24 Hoffman PC, Sievert SJ, Shaver RD, Welch DA and Combs DK, In situ dry matter, protein, and fiber degradation of perennial forages. J Dairy Sci 76:2632-2643 (1993). 
25 Sari YW, Syafitri U, Sanders JP and Bruins ME, How biomass composition determines protein extractability. Indust Crop Product 70:125-133 (2015).

26 Rancour D, Marita J and Hatfield RD, Cell wall composition throughout development for the model grass Brachypodium distachyon. Frontiers Plant Sci 3:266 (2012).

27 Buxton DR, Quality-related characteristics of forages as influenced by plant environment and agronomic factors. Anim Feed Sci Technol 59:37-49 (1996).

28 Krawutschke M, Kleen J, Weiher N, Loges R, Taube F and Gierus M, Changes in crude protein fractions of forage legumes during the spring growth and summer re-growth period. J Agric Sci 151:72-90 (2013).

29 Elizalde JC, Merchen NR and Faulkner DB, Fractionation of fiber and crude protein in fresh forages during the spring growth. J Anim Sci 77:476-484 (1999).

30 Gierus M, Herrmann A, Kruse S, Kleen J, Taube F, Lloveras J et al., Variation in the non-protein nitrogen content (fraction A) of several forages during the growing period. Grassland Sci Europe 11:595-597 (2006).

31 McDonald P, Edwards RA, Greenhalgh JF and Morgan CA, Animal Nutrition, 5th edition. Pearson Education Publishers, Essex, pp. 49-127 (1995).

32 Buxton DR and Marten GC, Forage quality of plant parts of perennial grasses and relationship to phenology. Crop Sci 29:429-435 (1989).

33 Weiher N, Krawutschke M, Gierus M, Taube F, Pötsch EM, Krautzer B et al., Effects of oven- or freeze-drying on protein fractions of red clover and relationship with specific polyphenol oxidase activity, in Grassland Farming and Land Management Systems in Mountainous Regions; Proceedings of the $16^{\text {th }}$ Symposium of the European Grassland Federation, 29-31 Aug., Raumberg-Gumpenstein, Grassland Science in Europe, Wageningen, pp. 262-264 (2011).
34 Grabber JH, Protein fractions in forage legumes containing proteinbinding polyphenols: Freeze-drying vs. conservation as hay or silage. Anim Feed Sci Technol 151:324-329 (2009).

35 Wiseman J and Cole DJ (eds), Feedstuff Evaluation. Elsevier, Butterworths, London (2013).

36 Machacek KJ and Kononoff PJ, The relationship between acid detergent insoluble nitrogen and nitrogen digestibility in lactating dairy cattle. Profess Anim Sci 25:701 -708 (2009).

37 Sniffen CJ, O'Connor JD, Van Soest PJ, Fox DG and Russell JB, A net carbohydrate and protein system for evaluating cattle diets: II. Carbohydrate and protein availability. J Anim Sci 70:3562-3377 (1992).

38 McKenzie DR, Yields of protein extracted from a range of northern Victorian herbage. Anim Product Sci 17:268-276 (1977).

39 Nanda $\mathrm{CL}$, Ternouth $\mathrm{JH}$ and Kondos AC, An improved technique for plant protein extraction. J Sci Food Agric 26:1917-1924 (1975).

40 Luis B, Reshamwala S, Latimer VM, Shawky BT, Dale BE and Stuart $E D$, Integrated production of ethanol fuel and protein from coastal bermudagrass. Appl Biochem Biotechnol 45:483-497 (1994).

41 Oldfield DJ, Taylor MW and Singh H, Effect of preheating and other process parameters on whey protein reactions during skim milk powder manufacture. Int Dairy J 15:501-511 (2005).

42 Dale BE, Allen MS, Laser M and Lynd LR, Protein feeds coproduction in biomass conversion to fuels and chemicals. Biofuels Bioprod Biorefin 3:219-230 (2009).

43 Amon T, Kryvoruchko V, Amon B, Bodiroza V, Zollitsch W, Boxberger $\mathrm{J}$ et al., Biogas production from grassland biomass in the Alpine region. Landtechnik 60:336-337 (2005).

44 Springer TL and Aiken GE, Harvest frequency effects on white clover forage biomass, quality, and theoretical ethanol yield. Biomass Bioenergy 78:1-5 (2015) 